\title{
Exploring high charge of phosphate as new draw solute in a forward osmosis-membrane distillation hybrid system for concentrating high-nutrient sludge
}

\author{
Nguyen Cong Nguyen ${ }^{a, d}$, Hau Thi Nguyen ${ }^{a, d}$, Su-Thing Ho ${ }^{a}$, Shiao-Shing Chen ${ }^{a}$, , Huu Hao Ngo ${ }^{b}$, \\ Wenshan Guo ${ }^{b}$, Saikat Sinha Ray ${ }^{a}$, Hung-Te Hsu ${ }^{c}$ \\ a Institute of Environmental Engineering and Management, National Taipei University of Technology, No. 1, Sec. 3, \\ Chung-Hsiao E. Rd, Taipei 106, Taiwan, ROC \\ b School of Civil and Environmental Engineering, Faculty of Engineering and Information Technology, University of \\ Technology Sydney, Broadway, NSW 2007, Australia \\ Department of Environmental Engineering, Chung Yuan Christian University, Chung Li 32023, Taiwan, ROC \\ d Faculty of Environment and Natural Resources, DaLat University, Viet Nam \\ Corresponding authors. \\ E-mail addresses: f10919@ntut.edu.tw (S.-S. Chen), h.ngo@uts.edu.au (H.H. Ngo).
}

\begin{abstract}
For the first time, a high charge of phosphate was used as the draw solute in a forward osmosis-membrane distillation (FO-MD) hybrid system for concentrating high-nutrient sludge. A high water flux $\left(12.5 \mathrm{~L} / \mathrm{m}^{2} \mathrm{~h}\right)$ and a low reverse salt flux $\left(0.84 \mathrm{~g} / \mathrm{m}^{2}\right)$ were simultaneously achieved at $\mathrm{pH} 9$ by using $0.1 \mathrm{M} \mathrm{Na}_{3} \mathrm{PO}_{4}$ as the draw solute and deionized water as the feed solution in the FO process. The specific reverse salt flux of $0.1 \mathrm{M} \mathrm{Na}_{3} \mathrm{PO}_{4}\left(J_{\mathrm{s}} / \mathrm{J}_{\mathrm{w}}=0.07 \mathrm{~g} / \mathrm{L}\right)$ was considerably less than that of $0.1 \mathrm{M} \mathrm{NaCl}\left(J_{s} / J_{\mathrm{w}}=0.37 \mathrm{~g} / \mathrm{L}\right)$ because the complexion between $\mathrm{Na}^{+}$and $\mathrm{HPO}_{4}{ }^{2-}$ at $\mathrm{pH} 9$ led to the reduction of free $\mathrm{Na}^{+}$ions, which subsequently reduced the reverse salt diffusion substantially. Moreover, for a feed solution with an initial sludge concentration of $3500 \mathrm{mg} / \mathrm{L}$, the sludge concentration could be concentrated to 19,800 and $22,000 \mathrm{mg} / \mathrm{L}$ in the pressure-retarded osmosis (PRO) and FO membrane orientations, respectively, after $15 \mathrm{~h}$ of operation. Four types of MD membranes were selected for draw solution recovery; of these, a polytetrafluoroethylene membrane with a pore size of $0.45 \mu \mathrm{m}$ was the most effective in achieving a high water flux $\left(10.28 \mathrm{~L} / \mathrm{m}^{2} \mathrm{~h}\right.$ ) and high salt rejection (approximately $100 \%$ ) in a diluted $\mathrm{Na}_{3} \mathrm{PO}_{4}$ draw solution.
\end{abstract}

Keywords: Forward osmosis; Membrane distillation; Draw solution; High charge Complexion 


\section{Introduction}

A large amount of sludge with a high-water-nutrient content, especially nitrogen and phosphorus, is often produced in wastewater treatment plants (Bourioug et al., 2015). Consequently, sludge dewatering is obligatory for such treatment plants and accounts for approximately $50 \%-60 \%$ of the total operating cost of the entire wastewater treatment plant (Appels et al., 2008; Rai et al., 2004). Although conventional sludge dewatering techniques such as clarification, gravity thickening are simple, the clarification is difficult to meet stringent regulations for effluent water quality and the sludge retention time is long and an unpleasant odor is emitted in gravity thickening process (Kim et al., 2010; Wang et al., 2008). Furthermore, the high-nutrient-rich centrate obtained from the stabilization of digested sludge increases the influent nitrogen loading by $15 \%-20 \%$ and phosphorus loading by $8 \%$ after combining with raw wastewater (Fux et al., 2002; Wild et al., 1997). This is a major challenge because the conventional biological process can reduce the biochemical oxygen demand considerably, but it does not reliably achieve the target discharge limits for nitrogen and phosphorus.

To solve the problems of conventional sludge dewatering technologies and shorten sludge treatment processes, Wang et al. (2008) used polyvinylidene fluoride membranes (microporous membranes) for performing sludge thickening and digestion during 1 cycle (2 days). This sludge reduction system is actually a membrane bioreactor (MBR) offering the advantages of a small footprint, high pollutant removal efficiency, and considerably low sludge volume. However, the main limitations of the dewatering process are the high amount of energy required for operation and quick membrane fouling. In contrast to the conventional MBR, several researchers have shown that forward osmosis (FO) performs better in membrane fouling control (Achilli et al., 2009; Cornelissen et al., 2008; Lay et al., 2011). In FO, natural osmosis is the driving force for separation, and therefore FO is expected to (1) have low energy requirements for operation; (2) achieve a high rejection of many pollutants; and (3) exhibit less fouling than pressure-driven membrane processes (Cornelissen et al., 2008; Nguyen et al., 2013). These apparent benefits have recently attracted many researchers to explore the FO technique, and promising results have been reported in a variety of fields such as wastewater treatment (Holloway et al., 2014; Nguyen et al., 2015b; Nguyen et al., 2015c; Nguyen et al., 2016), sludge dewatering (Hau et al., 2014; Nguyen et al., 2013), food processing (Petrotos and Lazarides, 2001), and the concentration of algae (Buckwalter et al., 2013). However, the major challenge in creating a marketable FO technology is the lack of an ideal draw solution that can achieve a high water flux, low reverse salt flux, and easy recovery (Nguyen et al., 2015b).

Many different draw solutes have been studied over the past several decades. Achilli et al. (2010) used monovalent salts (e.g., $\mathrm{NaCl}, \mathrm{KCl}$, and $\mathrm{NH}_{4} \mathrm{Cl}$ ) as the draw solutes for specific $\mathrm{FO}$ applications. Although these monovalent salts could generate high osmotic pressure and be reconcentrated to high concentrations through the reverse osmosis process, the draw solution recovery involved high cost and high reverse salt flux. McGinnis and Elimelech (2007) observed that a thermolyte solution containing ammonia carbon could be employed as a novel draw solute in the FO process with a cost-effective solute recovery system, whereas the high reverse salt flux of $\mathrm{NH}_{4} \mathrm{HCO}_{3}$ was crucial. To overcome the reverse salt diffusion of monovalent salts, Tan and $\mathrm{Ng}$ (2010) investigated this issue using divalent salts $\left(\mathrm{MgSO}_{4}\right.$ and $\left.\mathrm{CaCl}_{2}\right)$ as the draw solutes in $\mathrm{FO}$ process. Results showed that FO membrane could maintain at over 99.4\% for all divalent salts, subsequently reduced replenishment cost.

The synthesis of magnetic nanoparticles (MNPs) could provide another approach for designing an innovative draw solute without salt leakage for the FO process. However, particle aggregation during draw solution recycling could decrease their osmotic pressure as well as water flux considerably (Bai et al., 2011; Ge et al., 2011; Ling et al., 2010). Thus, insufficient reuse of MNPs in the FO process is a major obstacle hindering the widespread use of MNPs. Verv recentlv considerable progress has been made in developing synthetic materials for use as draw solutes, hydroacid complexes, polyelectrolytes, polymer hydrogels, and stimuliresponsive polymers (Ge et al., 2012a, 2014; Li et al., 2013; Zhao et al., 2014). Although the regeneration and reverse leakage of these innovative synthetic draw solutes have been improved, problems of poor repeatability, insufficient water flux, inability to generate high osmotic pressures at low viscosities, and a complex synthesis process persist [3]. In our previous study, high charge of EDTA was used as the draw solute in a hybrid FO-nanofiltration (NF) process for dewatering high-nutrient-containing sludge (Hau et al., 2014). Although EDTA sodium salt could obtain a low reverse salt flux, the viscosity of organic draw solutions (i.e. EDTA) increased quickly at high concentration, which prevent permeate water flux through FO membrane, and the recovery of the diluted draw solution by using an NF membrane was incomplete (salt rejection of 93\%), which motivated the author to carry out this work.

Based on our research, this approach is the first to use high charge of phosphate as the draw solute in an FO-membrane distillation (FO-MD) hybrid system for concentrating high-nutrient sludge. The current work aims to evaluate feasibility of applying FO-MD system on sludge dewatering for conventional treatment to simultaneously improve the effluent water quality. In this study, the performance of $\mathrm{Na}_{3} \mathrm{PO}_{4}$ salt as the draw solute in an FO process was symmetrically investigated for concentrating high-nutrient sludge. First, the effect of the draw solution $\mathrm{pH}$ and concentration on the FO performance was evaluated using deionized (DI) water as the feed solution. Next, the FO performance in terms of sludge dewatering was examined using high-nutrient sludge as the feed solution. Finally, to determine the most appropriate membrane, the diluted $\mathrm{Na}_{3} \mathrm{PO}_{4}$ draw solution was recovered after FO tests by using four types of MD membranes.

\section{Materials and methods}

\subsection{Feed and draw solutions}

FO experiments were conducted using DI water and high-nutrient sludge as the feed solutions. Activated sludge was collected from the municipal wastewater treatment plant in Taipei, Taiwan, and the mixed liquor suspended solid (MLSS) concentration was $3500 \mathrm{mg} / \mathrm{L}$. A solution containing D-glucose, $\mathrm{NH}_{4} \mathrm{Cl}$, and $\mathrm{K}_{2} \mathrm{HPO}_{4}$ was added to the raw activated sludge before its use as a feed solution to prepare a synthetic sludge with high nutrient concentration containing $300 \pm$ $5 \mathrm{mg} / \mathrm{L}$ of dissolved organiç carbon (DOC), $100 \pm 2 \mathrm{mg} / \mathrm{L}$ of $\mathrm{NH}_{4}^{+}-\mathrm{N}$, and $100 \pm 3 \mathrm{mg} / \mathrm{L}$ of $\mathrm{PO}_{4}{ }^{3}-\mathrm{P}$ (Table 1 ). Different concentrations (0.05, 0.1, 0.2, 0.3 , and $0.4 \mathrm{M}$ ) of the draw solution were prepared using laboratory-grade $\mathrm{Na}_{3} \mathrm{PO}_{4} \cdot 12 \mathrm{H}_{2} \mathrm{O}$ (Merck Co. Ltd., Germany). Because the formation of highly charged species of phosphate depends strongly on the $\mathrm{pH}, \mathrm{Na}_{3} \mathrm{PO}_{4}$ solutions with different $\mathrm{pH}$ values $(11,10,9$, 8,7 , and 5) were obtained from the $\mathrm{Na}_{3} \mathrm{PO}_{4}$ solution with original $\mathrm{pH} 12$ by using $\mathrm{H}_{3} \mathrm{PO}_{4}$ solution.

\section{2. $\mathrm{FO}$ and $\mathrm{MD}$ membranes}

Commercial thin film composite (TFC) FO membranes (OsMem ${ }^{\mathrm{TM}}$ TFC-ES Membrane 130424; HTI, USA) were used in all the FO experiments. Three types of polytetrafluoroethylene (PTFE) MD membranes with different pore sizes $(0.1,0.45$, and $1 \mu \mathrm{m})$ were provided by Ray-E Creative Co., Ltd., Taiwan, and a polypropylene (PP) MD membrane was provided by Klean Filter, Inc., Taiwan. Characteristics of the FO

Table 1

Characteristics of synthetic high-nutrient sludge as feed solution.

\begin{tabular}{lllll}
\hline MLSS (mg/L) & DOC $(\mathrm{mg} / \mathrm{L})$ & $\mathrm{pH}$ & $\mathrm{NH}_{4}^{+}-\mathrm{N}(\mathrm{mg} / \mathrm{L})$ & $\mathrm{PO}_{4}^{3}-\mathrm{P}(\mathrm{mg} / \mathrm{L})$ \\
\hline $3500 \pm 24$ & $300 \pm 5$ & $7.4 \pm 0.3$ & $100 \pm 2$ & $100 \pm 3$ \\
$\mathrm{Na}(\mathrm{mg} / \mathrm{L})$ & $\mathrm{Ca}(\mathrm{mg} / \mathrm{L})$ & $\mathrm{Zn}(\mathrm{mg} / \mathrm{L})$ & $\mathrm{Cu}(\mathrm{mg} / \mathrm{L})$ & $\mathrm{Ni}(\mathrm{mg} / \mathrm{L})$ \\
$126 \pm 2$ & $100 \pm 3$ & $3.48 \pm 0.15$ & $0.99 \pm 0.06$ & $0.18 \pm 0.04$ \\
\hline
\end{tabular}


and MD membranes were provided in Table 2. The mean pore size of the TFC FO membrane were determined based on reference (Xie et al., 2014), and the mean pore sizes of the MD membranes were provided from the manufacturer. The contact angle of FO and MD membranes was measured by using CAM 100 (Opto-Mechatronics P Ltd., India).

\subsection{Experimental setup}

Experiments involving an FO-MD hybrid system were conducted using the lab-scale circulating setup shown in Fig. 1. The FO test cell (FO Sterlitech, USA) was designed to have symmetric channels on both sides for the feed and draw solutions; each channel was $4.5 \mathrm{~cm}$ in width, $9.2 \mathrm{~cm}$ in length, and $0.2 \mathrm{~cm}$ in height. The total effective TFC-FO membrane area for mass transfer was $41.40 \mathrm{~cm}^{2}$. Two peristaltic pumps (Masterflex L/S Drive, Model 7518-00) were used to continuous-

ly circulate the feed and draw solutions on both sides of the FO membrane; the flow rate of the feed solution was identical to that of the draw solution $(0.5 \mathrm{~L} / \mathrm{min})$. A $0.2 \mathrm{M} \mathrm{Na}_{3} \mathrm{PO}_{4}$ draw solution with working volume of $3 \mathrm{~L}$ was circulated from the draw solution reservoir to the membrane cell for concentrating high-nutrient sludge during $15 \mathrm{~h}$ of FO operation (experimental batch). Conductivity and $\mathrm{pH}$ sensors were installed in the containers holding the feed and draw solutions to monitor changes in the respective parameters. The presence of mass transport across the membrane was determined by measuring weight changes in the feed solution container using a weighing scale (BW12KH, Shimadzu, Japan) to calculate the water flux.

After the FO tests were conducted, the diluted $\mathrm{Na}_{3} \mathrm{PO}_{4}$ draw solution was recovered through a laboratory-scale cross-flow MD membrane cell (Ray-E Creative Co., Ltd., Taiwan). The membrane cell was made of acrylic and consisted of two semi-cells. Each semi-cell had a flow channel with a depth, width, and length of $0.3,10$, and $10 \mathrm{~cm}$, respectively. Moreover, a $0.1-\mathrm{cm}$-thick spacer was used in the feed and distillate channels to increase the turbulence and mix the fluids, resulting in an increase in the water flux of the systems (Duong et al., 2015). The effective membrane area for mass transfer was $100 \mathrm{~cm}^{2}$. A peristaltic pump (Baoding Longer Precision Pump Co., Ltd., Taiwan) with two pump heads served to circulate the feed and distillate solutions through each semi-cell with a flow rate of $1.5 \mathrm{~L} / \mathrm{min}$. In the MD section, the $\mathrm{Na}_{3} \mathrm{PO}_{4}$ solution $(1 \mathrm{~L})$ controlled temperature of $50 \pm$ $1{ }^{\circ} \mathrm{C}$ was continuously pumped from a feed reservoir to the membrane cell, and it subsequently returned to the reservoir (Fig. S1). DI water was used as the initial distillate stream. The distillate $\left(25 \pm 1^{\circ} \mathrm{C}\right)$ was circulated from a $1 \mathrm{~L}$ reservoir through the distillate membrane semi-cell and back to the reservoir. Excess permeating water overflowed into a container, which was continuously weighed on an analytical balance.

\subsection{Measurement of water flux, reverse salt flux, and solute rejection}

The experimental water flux $\mathrm{J}_{\mathrm{w}}$, given in the unit of liters per square meter per hour $\left(\mathrm{L} / \mathrm{m}^{2} \mathrm{~h}\right)$ was acquired from the volume change of the feed solution using Eq. (1):

$J_{\mathrm{w}}=\frac{\Delta V}{A \Delta t}$

Table 2

Characteristics of the FO and MD membranes.

\begin{tabular}{llcl}
\hline Membrane & Pore size & Contact angle & Hydrophobic/hydrophilic \\
\hline TFC FO & $0.47 \mathrm{~nm}$ & $35 \pm 1^{\circ}$ & Highlyhydrophilic \\
PTFE MD & $0.1 \mu \mathrm{m}$ & $126 \pm 5^{\circ}$ & Hydrophobic \\
PTFE MD & $0.45 \mu \mathrm{m}$ & $114 \pm 4^{\circ}$ & Hydrophobic \\
PTFE MD & $1.0 \mu \mathrm{m}$ & $126 \pm 2^{\circ}$ & Hydrophobic \\
PP MD & $0.1 \mu \mathrm{m}$ & $123 \pm 4^{\circ}$ & Hydrophobic \\
\hline
\end{tabular}

where $\Delta \mathrm{V}$ is the feed volume change over a predetermined time $\Delta \mathrm{t}$ (hour) and $\mathrm{A}$ is the effective FO membrane area (square meter). The reverse solute flux $\mathrm{J}_{\mathrm{s}}$, given the units of grams per square meter per hour $\left(\mathrm{g} / \mathrm{m}^{2} \mathrm{~h}\right)$ of $\mathrm{Na}_{3} \mathrm{PO}_{4}$ salt was determined by the conversion of its electrical conductivity measured by a conductivity meter when $\mathrm{Na}_{3} \mathrm{PO}_{4}$ salt dissociates in its aqueous solution as follows:

$J_{s}=\frac{V_{t} C_{t}-V_{0} C_{0}}{A t}$

where $\mathrm{C}_{t}$ and $\mathrm{V}_{\mathrm{t}}$ are the concentration and volume of the feed solution measured at time $t$, respectively, and $\mathrm{C}_{0}$ and $\mathrm{V}_{0}$ are the initial concentration and initial volume of the feed solution, respectively.

The specific reverse $e_{2}$ salt flux $\left(\mathrm{J}_{\mathrm{s}} / \mathrm{J}_{\mathrm{w}}, \mathrm{g} / \mathrm{L}\right)$ was defined as the ratio of the salit flux $\left(\mathrm{J}_{\mathrm{s}}, \mathrm{g} / \mathrm{m} \mathrm{h}\right)$ in the reverse direction to the water flux $\left(J_{\mathrm{w}}, \mathrm{L} / \mathrm{m} \mathrm{h}\right)$ in the forward direction, and it estimated the amount of draw solute lost per liter of water produced during FO.

The conductivity and phosphate rejection in MD process can be obtained from the following equation:

$R=\left(1-\frac{C_{\mathrm{P}}}{C_{\mathrm{Fi}}}\right) 100 \%$

where $\mathrm{R}$ is the conductivity or phosphate rejection, $\mathrm{C}_{\mathrm{P}}$ is the conductivity or phosphate concentration in the MD permeate, and $\mathrm{C}_{\mathrm{Fi}}$ is the initial feed concentration (diluted draw solution).

\subsection{Analytical methods}

TheCa ${ }^{2+}, \mathrm{Na}^{+}, \mathrm{PO}_{4}^{3-}-\mathrm{P}$, and $\mathrm{NH}_{4}^{+}-\mathrm{N}$ concentrations were analyzed using ion chromatography (ICS-90, Dionex) and an ultraviolet-visible spectrophotometer (Model DR-4000, Hach, Japan). Zinc, copper, and nickel concentrations were examined using flame atomic adsorption spectroscopy (GBC 932, GBC Scientific Equipment, Australia). Samples used for DOC analysis were first filtered using a $0.45 \mu \mathrm{m}$ filter paper and then analyzed using a total organic carbon analyzer (Aurora 1010C, OI Analytical Corporation, USA). The MLSS was measured using Methods 2540 D, described in Standard Methods for the Examination of Water and Wastewater (APHA, 2005). The solutions' osmolality was measured using an osmometer (Model 3320, Advanced Instruments, Inc., USA). The measured osmolality of the solutions was then converted to osmotic pressure by using the Morse equation as follows:

$\pi=(\Sigma \phi n C) R T$

where, $(\Sigma \phi \mathrm{n} \mathrm{C})$ represents total osmolality, $\mathrm{R}$ is the universal gas constant, and $\mathrm{T}$ is the absolute temperature.

Viscosity and conductivity were determined using a Vibro Viscometer (AD Company, Japan) and conductivity meter (SensION156, Hach, China), respectively. The contact angles of the selective layers of the TFC and MD membranes were measured using the sessile drop method on a CAM 100 (Opto-Mechatro nics P Ltd., India). The values were taken as an average of three replicate tests with a droplet volume of $10 \pm$ $1 \mu \mathrm{L}$. All measurements were taken at room temperature. The fouled mem- branes were observed using scanning electron microscopy and energy dispersive X-ray spectroscopy (SEM-EDS; Philips XL30).

\section{Results and discussion}

\subsection{Effect of $\mathrm{pH}$ on water flux and reverse salt flux}

Fig. 2a depicts the effect of the draw solution $\mathrm{pH}$ on the water flux and reverse salt flux when DI water was used as the feed solution and $0.1 \mathrm{M} \mathrm{Na}_{3} \mathrm{PO}_{4}$ salt was used as the draw solute in the FO process. Clearly, the water flux increases gradually from 11.85 to $13.18 \mathrm{~L} / \mathrm{m}^{2} \mathrm{~h}$ when the $\mathrm{pH}$ value of the draw solution declined from 11 to 7 in PRO mode (active layer facing the draw solution). This was because the addition of $\mathrm{H}_{3} \mathrm{PO}_{4}$ 


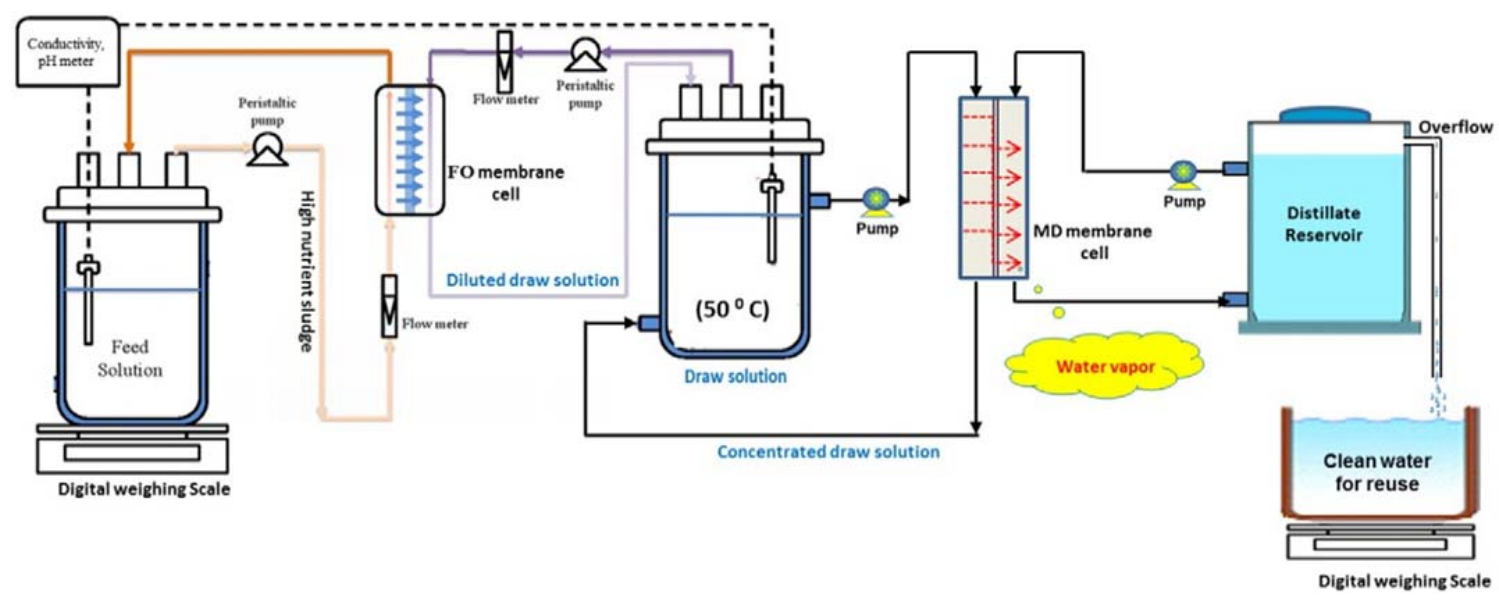

Fig. 1. Experimental setup of lab-scale FO-MD hybrid system.

for adjusting the draw solution $\mathrm{pH}$ from 11 to 7 slightly increased the osmolality from 357 to $378 \mathrm{mOsm} / \mathrm{kg} \mathrm{H}_{2} \mathrm{O}$. Nevertheless, the water flux decreased slightly when the draw solution $\mathrm{pH}$ was adjusted from 7 to 5 because of the strong influence of the FO membrane surface characteristics. Basically, the smaller contact angle of FO membrane corresponds to the more hydrophilic and higher wettability of membrane. At $\mathrm{pH} 7$, the FO TFC membrane was more hydrophilic (contact angle: $33.3^{\circ}$ ) than that at $\mathrm{pH} 5$ (contact angle: $37.5^{\circ}$ ), as shown in Fig. S2, and subsequently the membrane that was more hydrophilic showed a higher water flux (Ren and McCutcheon, 2014). Meanwhile, the reverse salt flux increased slightly from 0.81 to $0.84 \mathrm{~g} / \mathrm{m}^{2} \mathrm{~h}$ when the $\mathrm{pH}$ value of the draw solution declined from 11 to 9 , but the reverse salt flux increased quickly from 0.84 to $1.22 \mathrm{~g} / \mathrm{m}^{2} \mathrm{~h}$ with declining $\mathrm{pH}$ from 9 to 5. As shown in Fig. 2, the desirable value of the $\mathrm{Na}_{3} \mathrm{PO}_{4} \mathrm{pH}$ was 9. At this $\mathrm{pH}$, the specific reverse salt flux was the lowest $\left(\mathrm{J}_{\mathrm{s}} / \mathrm{J}_{\mathrm{w}}=0.07 \mathrm{~g} / \mathrm{L}\right)$ because the complexion between $\mathrm{HPO}_{4}^{2-}$ and $\mathrm{Na}^{+}$was $72.5 \%(\mathrm{a}$ complex formation was determined using MINEQL + on the basis of a chemical equilibrium model from the thermodynamic database) (Benjamin, 2002; Sawyer et al., 2003) as presented in Fig. S3, which
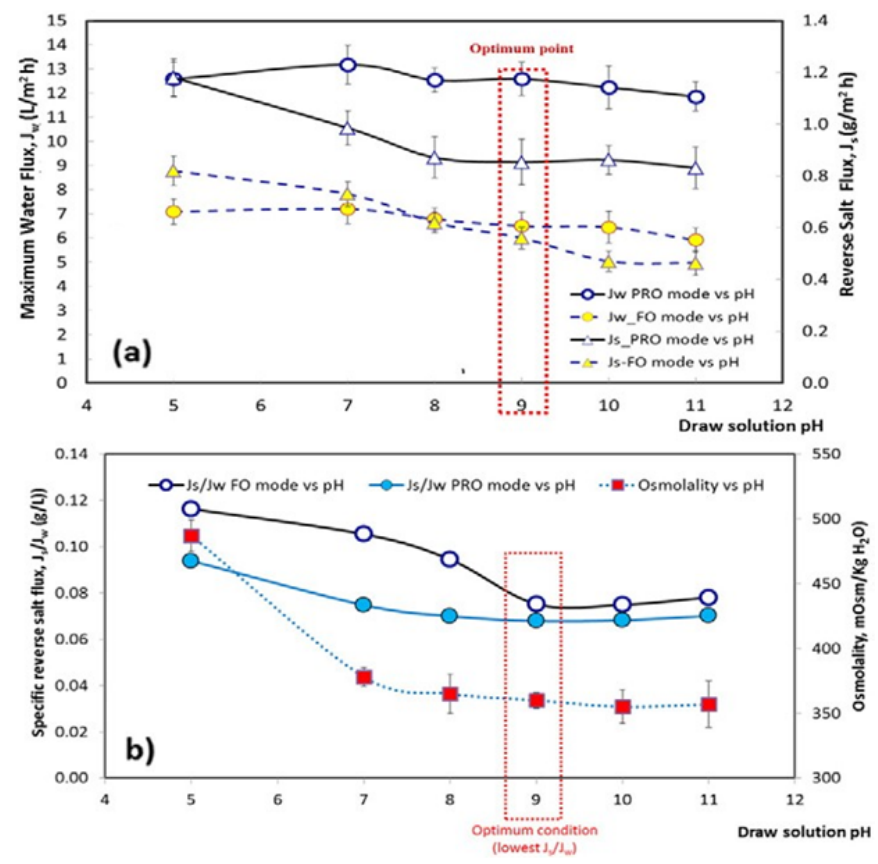

Fig. 2. Effect of draw solution $\mathrm{pH}$ values on (a) water flux and reverse salt flux; (b) osmolality and specific reverse salt flux (feed solution: DI water; draw solution: $0.1 \mathrm{M}$ $\mathrm{Na}_{3} \mathrm{PO}_{4}$, flow rate: $0.5 \mathrm{~L} / \mathrm{min}$, and experimental duration: $1 \mathrm{~h}$ ). reduced the number of free $\mathrm{Na}^{+}$ions considerably. Similarly, $\mathrm{pH} 9$ was the optimum condition in FO mode (active layer facing the feed solution), whereby the specific reverse salt flux was the lowest $\left(\mathrm{J}_{\mathrm{s}} /\right.$ $\mathrm{J}_{\mathrm{w}}=0.08 \mathrm{~g} / \mathrm{L}$ ) as shown in Fig. 2a and b. Nevertheless, the water flux in the FO mode was approximately 1.80-time lower compared to that of the PRO mode.

$\mathrm{NaCl}$ was also tested as a reference draw solute for comparison with $\mathrm{Na}_{3} \mathrm{PO}_{4}$ for a given concentration; its performance is presented in Fig. 3. For both membrane orientations, the water flux associated with $0.1 \mathrm{M}$ $\mathrm{Na}_{3} \mathrm{PO}_{4}$ was superior to that associated with the draw solution of $0.1 \mathrm{M} \mathrm{NaCl}$. The reverse salt flux of $0.1 \mathrm{M} \mathrm{Na}_{3} \mathrm{PO}_{4}\left(0.56 \mathrm{~g} / \mathrm{m}^{2} \mathrm{~h}\right.$ in the FO mode and $0.85 \mathrm{~g} / \mathrm{m}^{2} \mathrm{~h}$ in the PRO mode, at $\mathrm{pH}$ 9) was less than that of $\mathrm{NaCl}\left(1.84 \mathrm{~g} / \mathrm{m}^{2} \mathrm{~h}\right.$ in the FO mode and $2.17 \mathrm{~g} / \mathrm{m}^{2} \mathrm{~h}$ in the PRO mode). This indicates that the larger-sized, high charge of phosphate (hydrated radius: $0.339 \mathrm{~nm}$ ) in the $\mathrm{Na}_{3} \mathrm{PO}_{4}$ draw solution had a much lower reverse salt flux than did the smaller-sized chloride (hydrated radius: $0.195 \mathrm{~nm}$ ) in the $\mathrm{NaCl}$ draw solution (Kiriukhin and Collins, 2002).

\subsection{Effect of draw solution concentration on water flux and reverse salt flux}

As shown in Fig. 4a, when the $\mathrm{Na}_{3} \mathrm{PO}_{4}$ concentration increased from 0.05 to $0.2 \mathrm{M}$, the water flux increased rapidly from 4.61 to $9.02 \mathrm{~L} / \mathrm{m}^{2} \mathrm{~h}$ in the FO mode and from 8.57 to $16.20 \mathrm{~L} / \mathrm{m}^{2} \mathrm{~h}$ in the PRO mode. This may be due to the sharp increase in osmolality of the draw solution (from 191 to $580 \mathrm{mOsm} / \mathrm{kg} \mathrm{H}_{2} \mathrm{O}$ ) with increasing draw solution concentration (from 0.05 to $0.2 \mathrm{M}$ ). Nevertheless, the water flux increased slightly and approached a plateau for $\mathrm{Na}_{3} \mathrm{PO}_{4}$ concentrations that exceeded $0.2 \mathrm{M}$. Furthermore, between the concentrations of $0.2 \mathrm{M}$ $\left(\mathrm{J}_{\mathrm{w}}=9.02 \mathrm{~L} / \mathrm{m}^{2} \mathrm{~h}\right.$ in the FO mode and $\mathrm{J}_{\mathrm{w}}=16.20 \mathrm{~L} / \mathrm{m}^{2} \mathrm{~h}$ in the PRO mode) and $0.4 \mathrm{M}\left(\mathrm{J}_{\mathrm{w}}=9.62 \mathrm{~L} / \mathrm{m}^{2} \mathrm{~h}\right.$ in the $\mathrm{FO}$ mode and $\mathrm{J}_{\mathrm{w}}=18.19 \mathrm{~L} /$ $\mathrm{m}^{2} \mathrm{~h}$ in the PRO mode), the difference in the water flux was negligible

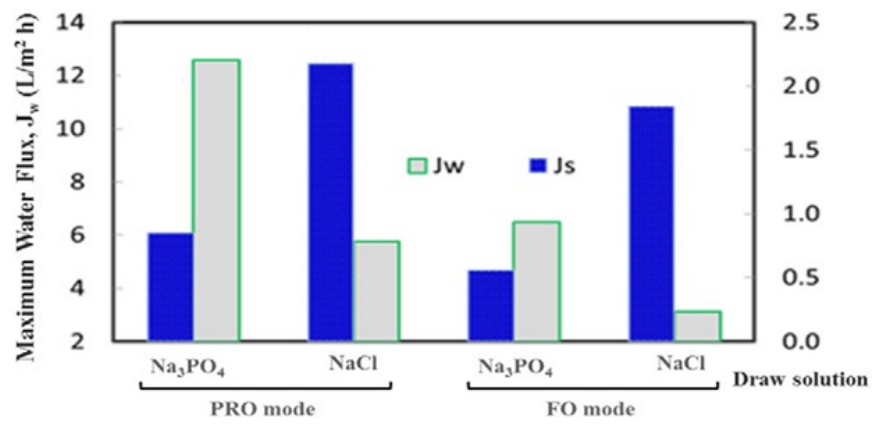

Fig. 3. Comparison of $0.1 \mathrm{M} \mathrm{NaCl}$ (osmolality of $170 \mathrm{mOsm} / \mathrm{kg} \mathrm{H}_{2} \mathrm{O}$ ) and $0.1 \mathrm{M} \mathrm{Na}_{3} \mathrm{PO}_{4}$ draw solution at pH 9 (osmolality of $360 \mathrm{mOsm} / \mathrm{kg} \mathrm{H}_{2} \mathrm{O}$ ) on water flux and reverse salt flux. Experimental duration: $1 \mathrm{~h}$. 


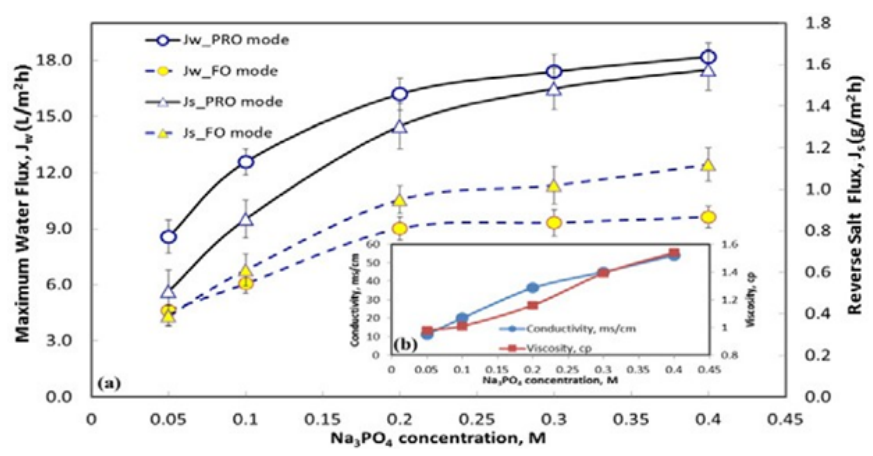

Fig. 4. (a) Effect of draw solution concentrations on water flux and reverse salt flux (feed solution: DI water; draw solution: $\mathrm{Na}_{3} \mathrm{PO}_{4}$ at $\mathrm{pH} 9$ and flow rate: $0.5 \mathrm{~L} / \mathrm{min}$ ); (b) Effect of draw solution concentration on conductivity and viscosity. Experimental duration: $1 \mathrm{~h}$.

because the viscosity increased from 1.16 to $1.45 \mathrm{cp}$ (Fig. 4b) and the concentration polarization prevented the permeable flux from the feed solution through the FO membrane (Yang et al., 2016). Studies from Zhao and Zou (2011) also revealed that higher viscosity and larger molecule sizes of draw solution were preferred to increase internal concentration polarization effect and reduce membrane performance, especially declined water flux.

Similarly, when the $\mathrm{Na}_{3} \mathrm{PO}_{4}$ concentration increased from 0.05 to $0.2 \mathrm{M}$, the reverse salt flux increased rapidly (from 0.39 to $0.95 \mathrm{~g} / \mathrm{m}^{2} \mathrm{~h}$ in the FO mode and from 0.51 to $1.30 \mathrm{~g} / \mathrm{m}^{2} \mathrm{~h}$ in the PRO mode) because the number of free $\mathrm{Na}^{+}$ions in the draw solution increased. However, the reverse salt diffusion showed a slight increase from 0.95 to $1.12 \mathrm{~g} /$ $\mathrm{m}^{2} \mathrm{~h}$ in the FO mode and from 1.30 to $1.57 \mathrm{~g} / \mathrm{m}^{2} \mathrm{~h}$ in the PRO mode when the draw solute concentration increased from 0.2 to $0.4 \mathrm{M}$. This may be due to the combined influence of the increased viscosity and concentration polarization at high $\mathrm{Na}_{3} \mathrm{PO}_{4}$ concentrations. This phenomenon was also recorded by Ge et al. (2012b) and Nguyen et al. (2015a) as the higher draw solution viscosity caused the lower exchange speed of draw solution on membrane sides leading to the higher concentration polarization degree, subsequently the declined water flux. The results showed that for the present study $0.2 \mathrm{M}$ to be the preferred concentration of $\mathrm{Na}_{3} \mathrm{PO}_{4}$ draw solution.

\subsection{Temporal variation of water flux and sludge concentration}

Fig. $5 \mathrm{a}$ and $\mathrm{b}$ show the temporal variations in water flux for both membrane orientations when $0.2 \mathrm{M} \mathrm{Na}_{3} \mathrm{PO}_{4}$ was used as the draw solute and the high-nutrient sludge (initial MLSS concentration: $3500 \mathrm{mg} / \mathrm{L}$ ) was used as the feed solution. Both the PRO and FO modes revealed a decreasing trend in the water flux as the running time increased, which was attributed to the dilution of the $\mathrm{Na}_{3} \mathrm{PO}_{4}$ draw solution, an increase in the salt concentration of the feed solution, and membrane fouling. Unlike the FO mode, the water flux in the PRO mode decreased sharply in the first $5 \mathrm{~h}$ (the water flux decreased from 11.50 to $6.13 \mathrm{~L} / \mathrm{m}^{2} \mathrm{~h}$ ) following the deposition of a thick sludge cake layer on the FO membrane surface. The reason for this is that the foulant was deposited more easily in the porous microstructure of the support layer when the high-nutrient sludge faced the support layer (Hau et al., 2014; Nguyen et al., 2013), leading to the membrane surface being partially covered by the visible foulant, as shown in Fig. 5a. In the scenario where the high-nutrient sludge faced the active layer of the FO membrane, the water flux decreased slightly in the first $5 \mathrm{~h}$ and remained relatively stable thereafter. The SEM image in Fig. $5 \mathrm{~b}$ shows a small amount of sludge attached to the membrane surface.

Moreover, the MLSS concentration increased rapidly with time in both the PRO and FO modes. After $15 \mathrm{~h}$ of operation, the MLSS concentration reached approximately 19,800 and $22,000 \mathrm{mg} / \mathrm{L}$ in the PRO and FO modes, respectively, suggesting that in real applications for concentrating high-nutrient sludge, the FO mode would be more efficient than the PRO mode in reducing membrane fouling. The concentrating sludge efficiency is comparable to the results of Wang et al. (2008), where flat-sheet membranes $(0.2-0.4 \mu \mathrm{m})$ were used to digestion of waste sludge and $30,000 \mathrm{mg} / \mathrm{L}$ thickened sludge was also achieved after 2 days. However, the membrane fouling was serious due to the increase of apparent viscosity of mixed liquors and the decrease of the cross-flow velocity along membrane surfaces (Wang et al., 2008). Meanwhile, in the current study, the sludge concentration could obtain $22,000 \mathrm{mg} / \mathrm{L}$ after $15 \mathrm{~h}-\mathrm{FO}$ operation and membrane fouling was observed slightly in FO mode.

\subsection{Recovery of diluted draw solution through MD}

When the high-nutrient sludge was concentrated during the FO process, the $\mathrm{Na}_{3} \mathrm{PO}_{4}$ draw solution was diluted with water permeating from

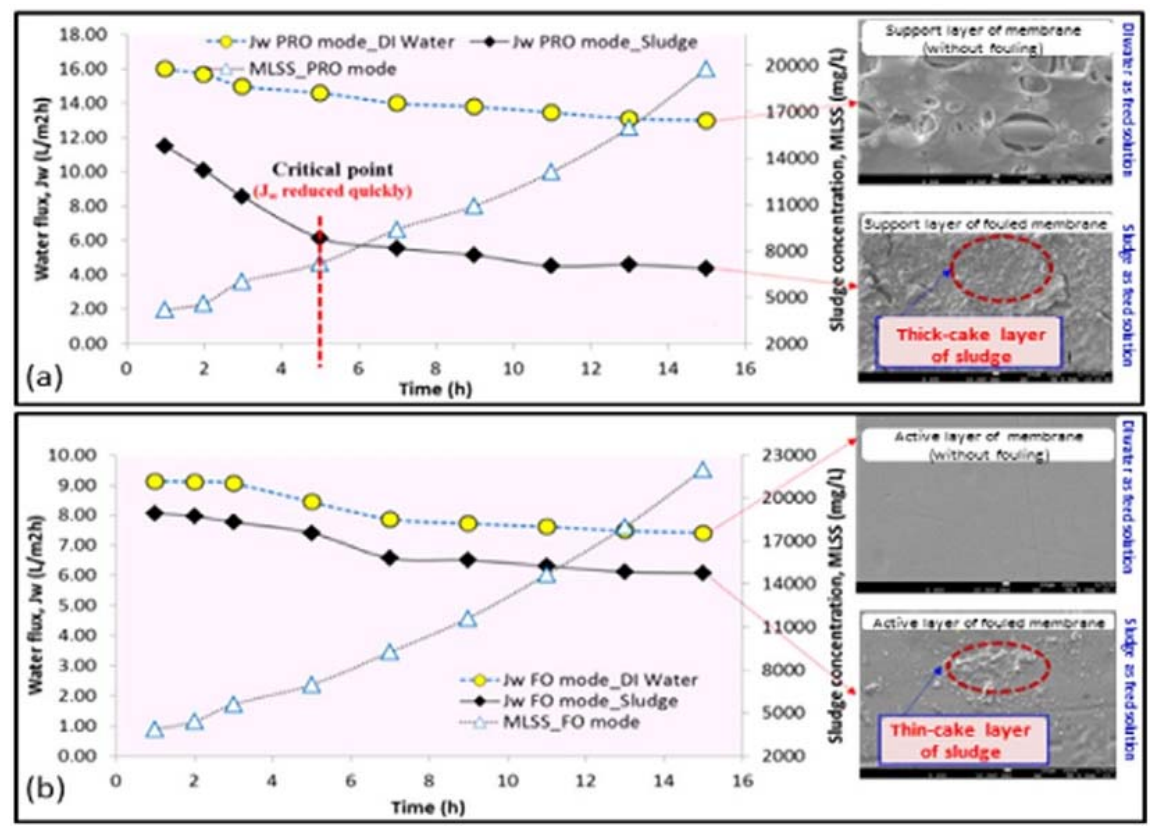

Fig. 5. Variations in water flux and sludge concentration via time (a) PRO mode: active layer facing the draw solution; (b) FO mode: active layer facing the feed solution.(Feed solution: high-nutrient sludge and DI water; draw solution: $0.2 \mathrm{M} \mathrm{Na}_{3} \mathrm{PO}_{4}$ salt at $\mathrm{pH}$ 9). 


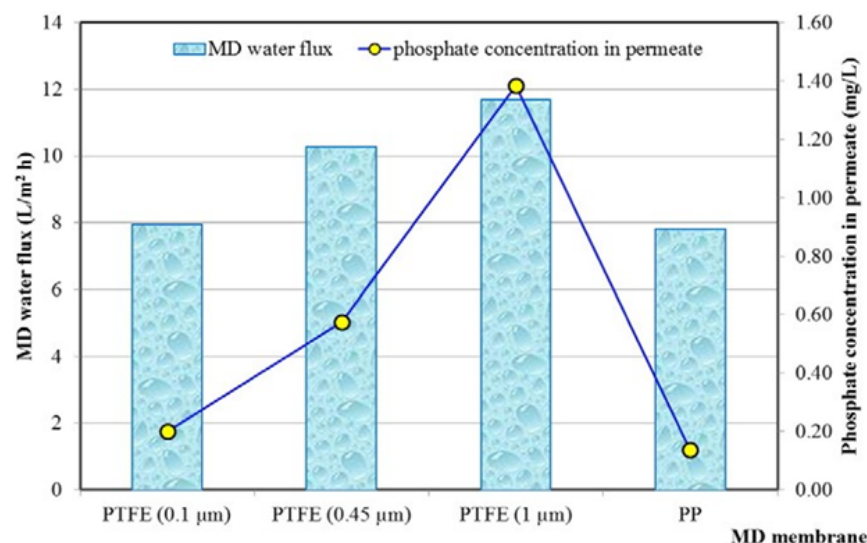

Fig. 6. The recovery of $\mathrm{Na}_{3} \mathrm{PO}_{4}$ draw solution with different kinds of MD membranes. (Diluted $\mathrm{Na}_{3} \mathrm{PO}_{4}$ draw solution as feed with initial phosphate concentration in of $15,620 \mathrm{mg} / \mathrm{L}$ and conductivity of $22,084 \mu \mathrm{S} / \mathrm{cm}$; feed temperature of $50{ }^{\circ} \mathrm{C}$ distillate temperature of $25^{\circ} \mathrm{C}$; feed and distillate flow rate of $1.5 \mathrm{~L} / \mathrm{min}$, experimental duration: $2 \mathrm{~h}$ ).

the sludge solution, and therefore it was necessary to recover the draw solution for reuse. To test their effectiveness, the recovery of $\mathrm{Na}_{3} \mathrm{PO}_{4}$ from the diluted $\mathrm{Na}_{3} \mathrm{PO}_{4}$ was investigated using four types of $\mathrm{MD}$ membranes. Fig. 6 shows the variation in phosphate-removal efficiency and the water flux for different MD membranes when the diluted $\mathrm{Na}_{3} \mathrm{PO}_{4}$ draw solution was used as feed. Results indicated that PTFE with a pore size of $1 \mu \mathrm{m}$ could provide the highest water flux $\left(11.68 \mathrm{~L} / \mathrm{m}^{2} \mathrm{~h}\right)$, followed by PTFE with a pore size of $0.45 \mu \mathrm{m}\left(10.28 \mathrm{~L} / \mathrm{m}^{2} \mathrm{~h}\right)$, PTFE with a pore size of $0.1 \mu \mathrm{m}\left(7.96 \mathrm{~L} / \mathrm{m}^{2} \mathrm{~h}\right)$, and $\mathrm{PP}\left(7.80 \mathrm{~L} / \mathrm{m}^{2} \mathrm{~h}\right)$. A possible reason for the difference is that the membrane pore radius influences both the vapor transport and it is therefore expected that membranes with larger pore size will yield higher MD flux. The reported result is consistent with previous study by Adnan et al. (2012), emphasizing the significant influence of pore size on the performance the MD processes. Moreover, the phosphate concentrations in permeate were $0.20,0.57,1.38$ and $0.14 \mathrm{mg} / \mathrm{L}$ when using PTFE $(0.1 \mu \mathrm{m})$, PTFE $(0.45 \mu \mathrm{m})$, PTFE $(1 \mu \mathrm{m})$, and PP $(0.1 \mu \mathrm{m})$, respectively. As shown in Fig. 6, the difference in the water flux between PTFE membranes with pore sizes of 1 and $0.45 \mu \mathrm{m}$ was not appreciable, but the membrane with a pore size of $0.45 \mu \mathrm{m}$ retained a considerably higher amount of phosphate. Therefore, the PTFE membrane with a pore size of $0.45 \mu \mathrm{m}$ was the preferred membrane for draw solution recovery with the conductivity rejection of approximately $100 \%$ (Table 3 ). The concentration of phosphate and conductivity in the PTFE $(0.45 \mu \mathrm{m})$ permeate were as low as $0.57 \mathrm{mg} / \mathrm{L}$ and $4.2 \mu \mathrm{S} / \mathrm{cm}$, respectively, which was suitable for water reuse (Sivakumar et al., 2015), while the final phosphate concentration in concentrated stream was $19,327 \mathrm{mg} / \mathrm{L}$.

\section{Conclusions}

The use of high charge of phosphate as a draw solute for concentrating high-nutrient sludge in an FO-MD hybrid system was successfully examined. At $\mathrm{pH} 9$, the $\mathrm{Na}_{3} \mathrm{PO}_{4}$ draw solution was suitable for providing a high water flux and mitigating salt leakage resulting from the formation of the high charge of phosphate and complexion. Results showed that the FO mode afforded a water flux (average water flux:

Table 3

Phosphate concentration in final concentrate and conductivity rejection of four kinds of MD membranes.

\begin{tabular}{llc}
\hline Membrane & $\begin{array}{l}\text { Phosphate concentration in final } \\
\text { concentrate }(\mathrm{mg} / \mathrm{L})\end{array}$ & $\begin{array}{c}\text { Conductivity } \\
\text { rejection, \% }\end{array}$ \\
\hline PTFE $(0.1 \mu \mathrm{m})$ & 18,212 & 100.00 \\
PTFE $(0.45 \mu \mathrm{m})$ & 19,327 & 100.00 \\
PTFE $(1 \mu \mathrm{m})$ & 19,523 & 99.99 \\
PP $(0.1 \mu \mathrm{m})$ & 18,206 & 100.00 \\
\hline
\end{tabular}

$7.09 \mathrm{~L} / \mathrm{m}^{2} \mathrm{~h}$ ) higher than that of the PRO mode (average water flux: $6.71 \mathrm{~L} / \mathrm{m}^{2} \mathrm{~h}$ ) because of less membrane fouling potential during the sludge dewatering process. After $15 \mathrm{~h}$ of operation, the MLSS concentration reached 19,800 and 22,000 mg/L in the PRO and FO modes, respectively. Furthermore, of those tested for recovering the diluted $\mathrm{Na}_{3} \mathrm{PO}_{4}$, the result for MD recovery showed that PTFE with a pore size of $0.45 \mu \mathrm{m}$ proved to be the most effective MD membrane, with approximately $100 \%$ conductivity rejection.

\section{Appendix A. Supplementary data}

Supplementary data to this article can be found online at http://dx. doi.org/10.1016/j.scitotenv.2016.03.025.

\section{References}

Achilli, A., Cath, T.Y., Marchand, E.A., Childress, A.E., 2009. The forward osmosis membrane bioreactor: a low fouling alternative to MBR processes. Desalination 239, 10-21.

Achilli, A., Cath, T.Y., Childress, A.E., 2010. Selection of inorganic-based draw solutions for forward osmosis applications. J. Membr. Sci. 364, 233-241.

Adnan, S., Hoang, M., Wang, H., Xie, Z., 2012. Commercial PTFE membranes for membrane distillation application: effect of microstructure and support material. Desalination 284, 297-308.

APHA, 2005. WEF Standard Methods for the Examination of Waters and Wastewaters. Washington DC

Appels, L., Baeyens, J., Degreve, J., Dewil, R., 2008. Principles and potential of the anaerobic digestion of waste-activated sludge. Prog. Energy Combust. Sci. 34, 755-781.

Bai, H., Liu, Z., Sun, D.D., 2011. Highly water soluble and recovered dextran coated $\mathrm{Fe}_{3} \mathrm{O}_{4}$ magnetic nanoparticles for brackish water desalination. Sep. Purif. Technol. 81, 392-399.

Benjamin, M.M., 2002. Water Chemistry. first ed. MrGraw-Hill, New York.

Bourioug, M., Fdr, Gimbert, Alaoui-Sehmer, L., Benbrahim, M., Aleya, L., Alaoui-Sossé, B., 2015. Sewage sludge application in a plantation: effects on trace metal transfer in soil-plant-snail continuum. Sci. Total Environ. 502, 309-314.

Buckwalter, P., Embaye, T., Gormly, S., Trent, J.D., 2013. Dewatering microalgae by forward osmosis. Desalination 312, 19-22.

Cornelissen, E.R., Harmsen, D., de Korte, K.F., Ruiken, C.J., Qin, J.-J., Oo, H., et al., 2008. Membrane fouling and process performance of forward osmosis membranes on activated sludge. J. Membr. Sci. 319, 158-168.

Duong, H.C., Chivas, A.R., Nelemans, B., Duke, M., Gray, S., Cath, T.Y., et al., 2015. Treatment of RO brine from CSG produced water by spiral-wound air gap membrane distillation - a pilot study. Desalination 366, 121-129.

Fux, C., Boehler, M., Huber, P., Brunner, I., Siegrist, H., 2002. Biological treatment of ammonium-rich wastewater by partial nitritation and subsequent anaerobic ammonium oxidation (anammox) in a pilot plant. J. Biotechnol. 99, 295-306.

Ge, Q., Su, J., Chung, T.S., Amy, G., 2011. Hydrophilic superparamagnetic nanoparticles: synthesis, characterization, and performance in forward osmosis processes. Ind. Eng. Chem. Res. 50, 382-388.

Ge, Q., Su, J., Amy, G.L., Chung, T.-S., 2012a. Exploration of polyelectrolytes as draw solutes in forward osmosis processes. Water Res. 46, 1318-1326.

Ge, Q., Wang, P., Wan, C., Chung, T.-S., 2012b. Polyelectrolyte-promoted forward osmosismembrane distillation (FO-MD) hybrid process for dye wastewater treatment. Environ. Sci. Technol. 46, 6236-6243.

Ge, Q., Fu, F., Chung, T.-S., 2014. Ferric and cobaltous hydroacid complexes for forward osmosis (FO) processes. Water Res. 58, 230-238.

Hau, N.T., Chen, S.-S., Nguyen, N.C., Huang, K.Z., Ngo, H.H., Guo, W., 2014. Exploration of EDTA sodium salt as novel draw solution in forward osmosis process for dewatering of high nutrient sludge. J. Membr. Sci. 455, 305-311.

Holloway, R.W., Wait, A.S., Fernandes da Silva, A., Herron, J., Schutter, M.D., Lampi, K., et al., 2014. Long-term pilot scale investigation of novel hybrid ultrafiltration-osmotic membrane bioreactors. Desalination.

Kim, H.-G., Jang, H.-N., Kim, H.-M., Lee, D.-S., Chung, T.-H., 2010. Effects of the sludge reduction system in MBR on the membrane permeability. Desalination 250, 601-604.

Kiriukhin, M.Y., Collins, K.D., 2002. Dynamic hydration numbers for biologically important ions. Biophys. Chem. 99, 155-168.

Lay, W.C.L., Zhang, Q., Zhang, J., McDougald, D., Tang, C., Wang, R., et al., 2011. Study of integration of forward osmosis and biological process: membrane performance under elevated salt environment. Desalination 283, 123-130.

Li, D., Zhang, X., Simon, G.P., Wang, H., 2013. Forward osmosis desalination using polymer hydrogels as a draw agent: influence of draw agent, feed solution and membrane on process performance. Water Res. 47, 209-215.

Ling, M.M., Wang, K.Y., Chung, T.S., 2010. Highly water-soluble magnetic nanoparticles as novel draw solutes in forward osmosis for water reuse. Ind. Eng. Chem. Res. 49, 5869-5876.

McGinnis, R.L., Elimelech, M., 2007. Energy requirements of ammonia-carbon dioxide forward osmosis desalination. Desalination 207, 370-382.

Nguyen, N.C., Chen, S.-S., Yang, H.-Y., Hau, N.T., 2013. Application of forward osmosis on dewatering of high nutrient sludge. Bioresour. Technol. 132, 224-229.

Nguyen, H.T., Nguyen, N.C., Chen, S.-S., Li, C.-W., Hsu, H.-T., Wu, S.-Y., 2015a. Innovation in draw solute for practical zero salt reverse in forward osmosis desalination. Ind. Eng. Chem. Res. 54, 6067-6074. 
Nguyen, H.T., Nguyen, N.C., Chen, S.-S., Ngo, H.H., Guo, W., Li, C.-W., 2015b. A new class of draw solutions for minimizing reverse salt flux to improve forward osmosis desalination. Sci. Total Environ. 538, 129-136.

Nguyen, N.C., Chen, S.-S., Nguyen, H.T., Ngo, H.H., Guo, W., Hao, C.W., et al., 2015c. Applicability of a novel osmotic membrane bioreactor using a specific draw solution in wastewater treatment. Sci. Total Environ. 518-519, 586-594.

Nguyen, N.C., Chen, S.-S., Nguyen, H.T., Ray, S.S., Ngo, H.H., Guo, W., et al., 2016. Innovative sponge-based moving bed osmotic membrane bioreactor hybrid system using a new class of draw solution for municipal wastewater treatment. Water Res. 91, 305-313. Petrotos, K.B., Lazarides, H.N., 2001. Osmotic concentration of liquid foods. J. Food Eng. 49, 201-206.

Rai, C.L., Struenkmann, G., Mueller, J., Rao, P.G., 2004. Influence of ultrasonic disintegration on sludge growth reduction and its estimation by respirometry. Environ. Sci. Technol. 38, 5779-5785.

Ren, J., McCutcheon, J.R., 2014. A new commercial thin film composite membrane for forward osmosis. Desalination 343, 187-193.

Sawyer, C.N., McCarty, P.L., Parkin, G.F., 2003. Chemistry for Environmental Engineering and Science. MrGraw-Hill, New York.

Sivakumar, M., Ramezanianpour, M., O'Halloran, G., 2015. Brackish water treatment for reuse using vacuum membrane distillation process. Water Sci. Technol. Water Supply $15,362-369$.
Tan, C.H., Ng, H.Y., 2010. A novel hybrid forward osmosis-nanofiltration (FO-NF) process for seawater desalination: draw solution selection and system configuration. Desalin. Water Treat. 13, 356-361.

Wang, Z., Wu, Z., Hua, J., Wang, X., Du, X., Hua, H., 2008. Application of flat-sheet membrane to thickening and digestion of waste activated sludge (WAS). J. Hazard. Mater. 154, 535-542.

Wild, D., Kisliakova, A., Siegrist, H., 1997. Prediction of recycle phosphorus loads from anaerobic digestion. Water Res. 31, 2300-2308.

Xie, M., Nghiem, L.D., Price, W.E., Elimelech, M., 2014. Relating rejection of trace organic contaminants to membrane properties in forward osmosis: measurements, modelling and implications. Water Res. 49, 265-274.

Yang, Q., Lei, J., Sun, D.D., Chen, D., 2016. Forward osmosis membranes for water reclamation. Sep. Purif. Rev. 45, 93-107.

Zhao, S., Zou, L., 2011. Relating solution physicochemical properties to internal concentration polarization in forward osmosis. J. Membr. Sci. 379, 459-467.

Zhao, D., Wang, P., Zhao, Q., Chen, N., Lu, X., 2014. Thermoresponsive copolymer-based draw solution for seawater desalination in a combined process of forward osmosis and membrane distillation. Desalination 348, 26-32. 